\title{
Dampak Pernikahan Usia Dini Terhadap Pola Asuh Dan Karakter Anak
}

\author{
${ }^{1}$ Gusnarib, ${ }^{2}$ Rosnawati \\ 1,2 Institut Agama Islam Negeri Palu \\ Jalan Diponegoro No.23, Lere, Kota Palu \\ E-mail: gusnarib@gmail.com
}

\begin{abstract}
The problems discussed in this research are what is the impact that occurs on parenting and the character of children born from early marriage? What factors support and inhibit early marriage?. The method used in this study is qualitative research, research location in the village of Lumbu Tarombo, South Banawa District, Donggala Regency. Data collection techniques used are field research. The results of the research was : (1) The impact that occurs on parenting and character of children born from early marriage. Early marriage has an impact on children's parenting that is not good, rough and hard and sometimes too spoils children so that children are born with whiny, temperamental, spoiled and stubborn characters. (2) Factors supporting the occurrence of early marriage in the research location include: economic factors, love, matchmaking and due to promiscuity and the factors that hinder the occurrence of early marriage in that location, namely: the application of Law No. 1 of 1974 concerning marriage and the number of local children who take formal education so that they can add insight into the early marriage that can be minimized
\end{abstract}

Keywords: Early marriage; Parenting; Character.

\begin{abstract}
Abstrak
Permasalahan yang dibahas dalam penelitian ini adalah bagaimana dampak yang terjadi pada pola asuh dan karakter anak yang terlahir dari pernikahan usia dini? Faktor-faktor apa saja yang mendukung dan menghambat terjadinya pernikahan usia dini?. Metode yang digunakan dalam penelitian ini yaitu penelitian kualitatif. Lokasi penelitian di desa Lumbu Tarombo Kecamatan Banawa Selatan, Kabupaten Donggala. Teknik pengumpulan data yang digunakan adalah penelitian lapangan. Hasil penelitian yang diperoleh yaitu : (1) Dampak yang terjadi pada pola asuh dan karakter anak yang terlahir dari pernikahan usia dini. Pernikahan usia dini berdampak pada pola asuh anak yang kurang baik, kasar dan keras serta terkadang terlalu memanjakan anak sehingga terlahir anak-anak dengan karakter yang cengeng, tempramen, manja dan keras kepala. (2) Faktor-faktor pendukung terjadinya pernikahan usia dini di lokasi penelitian antara lain: faktor ekonomi, cinta, perjodohan dan akibat pergaulan bebas serta faktor-faktor yang menghambat terjadinya pernikahan usia dini di lokasi tersebut yaitu: penerapan UU No. 1 tahun 1974 tentang perkawinan dan banyaknya anak-anak daerah yang menempuh pendidikan formal sehingga menambah wawasan mereka pada akhirnya pernikahan usia dini dapat diminimalisirkan
\end{abstract}

Kata Kunci: Pernikahan usia dini; Pola asuh; Karakter. 


\section{Pendahuluan}

Pernikahan merupakan jalan yang bisa ditempuh oleh manusia untuk membentuk suatu keluarga atau rumah tangga bahagia yang berdasarkan Ketuhanan Yang Maha Esa. Pernikahan pada umumnya dilakukan oleh orang dewasa atau orang yang sudah cukup matang fisik dan psikisnya agar dapat membentuk keluarga sejati yaitu keluarga yang sakinah, mawaddah dan warahmah dengan tidak memandang profesi, suku bangsa, kaya atau miskin, dan sebagainya. Batas usia dalam melaksanakan pernikahan sangatlah penting karena didalam pernikahan menghendaki kematangan fisik dan psikologisnya agar terhindar dari berbagai dampak negatif setelah pernikahan. Pernikahan yang sukses sering ditandai dengan kesiapan memikul tanggung jawab dan bersabar dalam menghadapi segala bentuk cobaan yang menerpa biduk rumah tangga. Namun, fenomena yang terjadi di masyarakat saat ini bertolak belakang dengan hal tersebut. Pernikahan bukanlah untuk orang-orang yang sudah dewasa (cukup umur), melainkan akhir-akhir ini banyak orang-orang (para remaja) yang belum cukup umur melangsungkan pernikahan yang biasa dikenal dengan pernikahan usia dini atau menikah di bawah umur/belum cukup umur.

Pernikahan dini atau pernikahan diusia muda adalah suatu ikatan lahir dan batin yang dilakukan oleh seorang pemuda dan pemudi yang belum mencapai taraf yang ideal untuk melakukan suatu pernikahan, dalam artian pernikahan yang dilakukan sebelum dewasa, hukumnya menurut syara adalah mandub (sunnah). ${ }^{1}$ Pada prinsipnya pernikahan anak di bawah umur banyak membawa mudarat atau dampak buruk dan tidak sedikit berakhir dengan kekerasan serta perceraian. Pernikahan usia dini melanggar hak anak, terutama anak perempuan sebagai pihak yang paling rentan menjadi korban dalam kasus pernikahan usia dini. Oleh karenanya, dalam tatanan masyarakat sebagian mereka menganggap bahwa pernikahan diusia dini atau pernikahan anak di bawah umur adalah hal yang tidak biasa namun sebagian masyarakat ada yang menganggap bahwa pernikahan diusia dini adalah hal yang biasa. Pernikahan diusia dini dilihat dari segi pelakunya dapat digolongkan kedalam 2 golongan, pertama pernikahan anak di bawah umur dengan orang dewasa, kedua pernikahan sesama anak di bawah umur. Menikahi anak di bawah umur oleh orang dewasa cenderung dianggap sebagai tindakan eksploitasi terhadap anak dan ditengarai bisa merusak cara

1Taqiyuddin An Nabhani, An Nizham Al Ijtima'I fi Al Islam. (Bandung: PT Al-Ma'arif, 1990), 101. 
berpikir dan masa depan anak. Sedangkan pernikahan sesama anak di bawah umur cenderung karena pergaulan anak dan opini yang berkembang di tengah masyarakat, tentu hal ini lebih berdampak buruk bagi masa depan anak yang dimaksud. Meskipun demikian, pernikahan anak di bawah umur dapat dilegalkan serta sah secara hukum melalui lembaga dispensasi nikah.

Dispensasi nikah merupakan salah satu kewenangan absolut yang diberikan oleh undang-undang kepada Pengadilan Agama untuk memeriksa, memutus, dan menyelesaikan perkara permohonan izin menikah bagi orangorang yang memiliki halangan menikah. Kewenangan ini tercantum pada Pasal 49 Undang-Undang Nomor 7 Tahun 1989 tentang Peradilan Agama yang menyatakan bahwa:

Pengadilan Agama bertugas dan berwenang memeriksa, memutus dan menyelesaikan perkara ditingkat pertama antara orang-orang yang beragama Islam dibidang: a). Perkawinan; b). Waris; c). Wasia; d). Hibah; e). Wakaf; f). Zakat; g). Infak; h). Shadaqah; dan i). Ekonomi syariah. ${ }^{2}$

Peran Pengadilan Agama melalui dispensasi nikah sangat signifikan dalam memberikan perlindungan anak. Hal ini disebabkan karena Pengadilan Agama memiliki kewenangan untuk menerima, memeriksa dan memutuskan perkara permohonan dispensasi nikah dengan pertimbangan hukum yang matang yang tidak terlepas dari pertimbangan sosiologis, historis dan filosofis. Namun, tidak sedikit para pihak yang menuding peran Pengadilan Agama tersebut dengan tudingan negatif. Karena meragukan penetapan pemberian izin kepada anak dibawah umur untuk menikah akan membawa kemaslahatan, justru banyak yang berpendapat akan menimbulkan mudarat dan berkontribusi terhadap kemunduran bangsa. Pernikahan dini dapat berdampak negatif bagi pelakunya seperti kekerasan dalam rumah tangga, serta dapat berdampak terhadap psikologi dan kesehatan pada remaja putri dan anak. ${ }^{3,4}$

Sehubungan dengan hal di atas, salah satu survey awal yang menjadi dasar ketertarikan peneliti untuk meneliti di Desa Lumbu Tarombo, Kec. Banawa Selatan, Kabupaten Donggala dikarenakan pernikahan dini di desa tersebut dianggap lumrah. Pernikahan usia dini di desa tersebut telah

\footnotetext{
${ }^{2}$ Mahkamah Agung RI, Undang-Undang Republik Indonesia No. 3 Tahun 2006, MARI: Jakarta, 2006. h, 20

${ }^{3}$ Riska Afriani and Mufdlilah, "Analisis Dampak Pernikana Dini Pada Remaja Putri Di Desa Sidoluhur Kecamatan Godean Yogyakarta,” Rakernas Aipkema, 2016.

${ }^{4}$ Agus Mahfudin; Khoirotul Waqi'ah, "Pernikahan Dini Dan Pengaruhnya Terhadap Keluarga Di Kabupaten Sumenep Jawa Timur,” Hukum Keluarga Islam, 2016.
} 
berlangsung cukup lama dan tentunya menimbulkan dampak baik bersifat positif maupun negatif hingga sangat baik dan menarik untuk dianalisa.

Desa Lumbu Tarombo adalah bagian dari daerah Tolongano yang memisahkan diri dan berdiri sendiri, tepatnya Januari 2008. Sebelum memisahkan diri dari desa Tolongano daerah Lumbu Tarombo memang sudah terkenal dengan pernikahan usia dini yang menurut salah satu penduduk aslinya bapak Dalle bahwa pernikahan usia dini berlangsung hingga di era 90-an memasuki tahun 2000 pernikahan usia dini di daerah tersebut mulai berkurang dikarenakan banyaknya anak-anak daerah yang menempuh pendidikan formal hingga mereka kembali dengan wawasan yang global serta setelah memasuki tahun 2010 ketika daerah tersebut berdiri sendiri menjadi desa Lumbu Tarombo maka peraturan semakin diperketat dan diterapkannya UU No. 1 Tahun 1974 tentang perkawinan yang membuat pernikahan diusia dini semakin jarang dijumpai.

Pendidikan formal dan penerapan peraturan UU No. 1 Tahun 1974 tentang perkawinan merupakan faktor-faktor penghambat terjadinya pernikahan usia dini di desa Lumbu Tarombo. Namun, tidak menutup kemungkinan pernikahan usia dini tetap terjadi di desa tersebut. Pada tahun 2016 desa Lumbu Tarombo digemparkan dengan kejadian pernikahan 5 remaja sekaligus yang masih berusia belia, mereka menikah dikarenakan cinta dan hamil diluar nikah yang mengharuskan pernikahan terjadi walau masih berusia dini.

Pernikahan usia dini di Desa Lumbu Tarombo mayoritas terjadi tanpa adanya dispensasi nikah dan tergolong kedalam pernikahan siri. Hal tersebut terjadi karena orangtua mereka menganggap pengurusan dispensasi nikah sangat sulit dan memakan biaya sehingga mereka melangsungkan pernikahan tanpa adanya izin dari Pengadilan Agama. Pernikahan usia dini di Desa Lumbu Tarombo tidak dapat dihilangkan hanya dapat diminimalisirkan. Walaupun pernikahan diusia dini dilakukan oleh anak-anak remaja tidak menutup kemungkinan terdapat pada diri mereka sikap dan prilaku dewasa yang membuat pernikahannya tetap berjalan lancar. Seperti pada kasus penelitian yang peneliti lakukan ini, peneliti menemukan 2 keluarga pelaku pernikahan usia dini yang mempunyai pola pikir dan berprilaku dewasa, sehingga mereka mampu menghadapi cobaan dan ujian yang menerpa biduk rumah tangga mereka hingga mereka mampu menjalaninya dengan bahagia.

Keluarga yang melangsungkan pernikahan diusia dini tidak dapat menghindari beberapa dampak negatif yang timbul dikarenakan usia mereka yang belum matang sehingga emosi mereka belum stabil yang sering memicu terjadinya perselisihan atau pertengkaran diantara mereka, hingga pada akhirnya Kekerasan Dalam Rumah Tangga (KDRT) tidak dapat dihindari baik 
itu dilakukan suami terhadap istrinya atau terhadap anaknya dan sebaliknya. Selain KDRT bebrapa dampak negatif yang peneliti temukan semua dikarenakan usia mereka yang menikah terlalu muda sehingga menimbulkan keguguran bagi para ibu yang mengandung terlalu muda, sikap otoriter dalam mengasuh dan mendidik anak-anak serta sifat posesif pasangan suami-istri yang menikah diusia dini sering menimbulkan perselisihan serta pertengkaran.

Pola asuh anak yang tidak optimal tentu bukanlah hal yang baik bagi keberlangsungan anak di masa depan. Terdapat beberapa faktor yang mempengaruhi pola asuh yaitu tingkat pendidikan orang tua, status sosial ekonomi, jumlah anak, usia dan jarak tempat tinggal ke sekolah. ${ }^{5}$ Keluarga merupakan tempat pertama kalinya untuk seorang anak memperoleh pendidikan dan mengenal nilai-nilai maupun peraturan-peraturan yang harus diikutinya yang mendasari anak untuk melakukan hubungan sosial dengan Iingkungan yang lebih luas. Menurut Baumrind yang dikutip oleh Muallifah, pola asuh pada prinsipnya merupakan parental control: "yakni bagaimana orangtua mengontrol, membimbing dan mendampingi anakanaknya untuk melaksanakan tugas-tugas perkembangannya menuju pada proses pendewasaan". ${ }^{6}$ Hersey dan Blanchard (Garliah, 2005) menjelaskan bahwa pola asuh adalah bentuk dari kepemimpinan. Pengertian dari kepemimpinan itu sendiri ialah bagaimana mempengaruhi seseorang, dalam hal ini orangtua berperan sebagai pengaruh yang kuat pada anaknya. ${ }^{7}$ Menurut Thoha pola asuh orang tua adalah suatu cara terbaik yang dapat ditempuh orang tua dalam mendidik anak sebagai perwujudan dari rasa tanggung jawab kepada anak. ${ }^{8}$ Peran keluarga menjadi sangat penting untuk mendidik anak baik dalam sudut tinjauan agama, tinjauan sosial kemasyarakatan maupun tinjauan individu.

Salah satu hal yang dapat dipengaruhi jika pola asuh anak tidak optimal yaitu perkembangan karakter anak. Menurut Hornby dan Parnwell yang dikutip oleh Abdul Majid dkk, karakter adalah kualitas mental atau moral, kekuatan moral, nama atau reputasi. Sedangkan menurut Hermawan yang dikutip oleh Abdul Majid dkk, karakter adalah ciri khas yang dimiliki oleh suatu benda atau individu. Ciri khas tersebut adalah asli dan mengakar pada

${ }^{5}$ Adpriyadi Adpriyadi And Sudarto Sudarto, "Pola Asuh Orang Tua Dan Implikasinya Terhadap Pendidikan Anak Usia Dini Pada Subsuku Dayak Inggar Silat," VOX EDUKASI: Jurnal Ilmiah Ilmu Pendidikan, 2019, https://doi.org/10.31932/ve.v10i2.538.

${ }^{6}$ Muallifah, Pshyco Islamic Smart Parenting, (tt: Diva Press Anggota IKAPI, 2009), 42.

${ }^{7}$ Lili Garliah dkk, Peran Pola Asuh Orangtua dalam Memotivasi Berprestasi, (Jurnal Psikologi, 2005), Vol. I, No. I.

8Thoha dkk, Metodologi Pengajaran Agama, (Yogyakarta: Pustaka Pelajar, 2004), 91. 
kepribadian benda atau individu tersebut dan merupakan mesin pendorong bagaimana seseorang bertindak, bersikap, berujar, dan merespon sesuatu. ${ }^{9}$

Desa Lumbu Tarombo selain dikenal dengan pernikahan diusia dini juga dikenal dengan persatuan dan kekeluargaan mereka yang sangat erat. Sehingga walaupun keluarga yang menikah diusia dini tersebut mengalami KDRT pemerintah desa jarang mengetahuinya karena pasangan yang mengalaminya tidak membesar-besarkan masalah tersebut, mereka dapat menyelesaikan bahkan tanpa bantuan keluarga besar mereka. Sehingga mereka dapat menjalani rumah tangga mereka dengan bahagia, nyaman, tentram dan sejahtera.

Terdapat beberapa penelitian yang mengkaji masalah pernikahan usia dini, pola asuk anak serta dampaknya. Al-Khutby (2018)10, Djamila dan Kartikawati (2014) ${ }^{11}$, Widyana, dkk (2018) ${ }^{12}$ serta Ahmad (2018) ${ }^{13}$ secara umum mengungkap bahwa penyebab pernikahan usia dini di daerah-daerah yang menjadi subjek penelitian mereka dikarenakan beberapa faktor diantaranya faktor ekonomi, pendidikan yang rendah, kurangnya pendidikan kesehatan reproduksi dan seksual, kecanggihan teknologi, pariwisata serta faktor adat/tradisi masyarakat setempat dan hamil di luar nikah. Selain itu juga diperoleh temuan bahwa ada perbedaan pola asuh anak antara pasangan yang menikah usia dini dengan pasangan yang menikah usia dewasa penuh

Mengacu pada penelitian-penelitian terdahulu dapat disimpulkan bahwa pernikahan dini bukanlah hal yang baru melainkan sesuatu hal yang sudah dianggap biasa oleh sebagian besar masyarakat. Pernikahan dini tentunya membawa dampak bagi keluarga terutama anak-anak yang terlahir dari pernikahan tersebut, dengan usia orangtua yang masih muda akan berdampak terhadap pola asuh anak yang berimbas pada karakter anak tersebut. Berdasarkan hal tersebut, peneliti tertarik untuk mengkaji dampak pernikahan dini terhadap pola asuh dan karakter anak di desa Lumbu Tarombo, Kec.Banawa Selatan, Kab. Donggala.

Berdasarkan latar belakang di atas, maka studi ini berkontribusi pada:

${ }^{9}$ Ibid

10 $\underline{\text { http://digilib.uin-suka.ac.id/21882/1/1420310095 BAB-I IV-atau-V DAFTAR }}$

PUSTAKA.pdfDi akses 14 Maret 2018

11https://journal.ugm.ac.id/jurnalpemuda/article/viewFile/32033/19357. Di akses 14 Maret 2018

${ }^{12}$ http://digilib.uin-suka.ac.id/21882/1/1420310095_BAB-IIV-atau-V_DAFTAR

PUSTAKA.pdfDi akses 14 Maret 2018

13http://repository.uinjkt.ac.id/dspace/bitstream/123456789/21872/1/ZULKIFLI\%

20AHMAD-FDK.pdf. Di akses 16 Februari 2018 
1. Dampak yang terjadi pada pola asuh dan karakter anak yang terlahir dari pernikahan usia dini di Desa LumbuTarombo Kecamatan Banawa Selatan Kabupaten Donggala

2. Menemukan faktor-faktor apa saja yang mendukung dan menghambat terjadinya pernikahan usia dini di Desa Lumbu Tarombo Kecamatan Banawa Selatan, Kabupaten Donggala.

Adapun tujuan yang ingin dicapai dalam penelitian ini yakni untuk mengetahui dampak yang terjadi pada pola asuh dan karakter anak yang terlahir dari pernikahan usia dini di Desa LumbuTarombo Kecamatan Banawa Selatan Kabupaten Donggala serta untuk mengetahui dan memahami factor-faktor apa saja yang mendukung dan menghambat terjadinya pernikahan usia dini di Desa Lumbu Tarombo, Kecamatan Banawa Selatan, Kabupaten Donggala.

\section{Metode}

Penelitian ini merupakan penelitian kualititaif. Langkah-langkah yang ditempuh dalam proses penelitian terdiri dari mengidentifikasi masalah, pembatasan masalah, menetapkan fokus penelitian, mengumpulkan data, pengolahan dan pemaknaan data, pemunculan teori atau pencocokan teori, dan pelaporan hasil penelitian.

Penelitian ini dilaksanakan di Desa Lumbu Tarombo, Kecamatan Banawa Selatan, Kabupaten Donggala dengan jumlah penduduk 1.368 jiwa, dan kepala keluarga $370 \mathrm{kk}$ serta terbagi kedalam 3 dusun. Di dusun I terdiri dari 102 kk dengan jumlah pernikahan usia dini 6 orang, di dusun II terdiri dari 147 kk dan yang menikah usia dini hanya 3 orang serta di dusun III terdiri dari $121 \mathrm{kk}$ dan yang menikah usia dini 5 orang.

Teknik pengumpulan data yang digunakan meliputi teknik observasi, dokumentasi dan wawancara. Adapun teknik analisis data terdiri dari data reduction (reduksi data), data display (penyajian data) dan verifikasi data. Keabasahan data penelitian ini ditentukan dengan menggunakan derajat kepercayaan (credibility), keteralihan (transferability), kebergantungan (dependability), dan kepastian (confirmability). Selain itu, terdapat pula teknik pemeriksaan keabsahan data yang digunakan yakni perpanjangan keikutsertaan, ketekunan atau keajegan pengamatan, serta triangulasi. 


\section{Dampak Pernikahan Usia Dini Terhadap Pola Asuh Dan Karakter Anak Yang Terlahir}

Desa Lumbu Tarombo adalah sebuah daerah yang dahulunya hanyalah sebuah dusun dari desa Tolongano yang pada akhirnya di tahun 2008 memisahkan diri dan berdiri sendiri menjadi sebuah desa dengan pemerintahan dan otonomi daerah tersendiri tanpa bergantung kepada desa Tolongano. Mengenai pernikahan usia dini di desa Lumbu Tarombo sudah terjadi sejak lama sebelum Lumbu Tarombo menjadi sebuah desa. Bapak Dalle sebagai salah satu tokoh masyarakat sekaligus penduduk asli desa Lumbu Tarombo berkomentar mengenai pernikahan usia dini di desanya, beliau menyatakan bahwa:

Pernikahan usia dini tidak harus dan tidak boleh dilakukan, karena sangat merugikan keluarga dan menjadi beban keluarga. Suku Bugis diusia 16 dan 17 tahun harus menikah, jadi kebanyakan yang menikah diusia dini di desa Lumbu Tarombo adalah suku bugis dan mandar, adapun suku kaili yang menikah diusia dini karena suku bugis dan mandar yang melamar karena bagi mereka jika umur 20 tahun belum menikah sudah dianggap perawan tua. ${ }^{14}$

Dari pendapat salah satu tokoh masyarakat sekaligus penduduk asli di desa Lumbu Tarombo yaitu bapak Dalle dan setelah mendengarkan cerita serta keterangan dari beliau selama proses penelitian peneliti dapat menyimpulkan bahwa pada awalnya di daerah tersebut tidak ada namanya pernikahan diusia dini pada waktu itu sebagian besar bahkan hampir seluruh masyarakatnya bersuku kaili, bagi para pemuda kaili hanya akan menikah ketika mereka sudah mapan dibidang sosial ekonomi dan sudah siap dari segi fisik, sikis dan spiritual untuk membina rumah tangga. Memasuki tahun 70an daerah tersebut banyak kedatangan orang-orang dan menetap untuk bertempat tinggal, sebagian besar mereka bersuku bugis dan mandar. Para pendatang tersebut masi memegang prinsip dan tradisi bahwa ketika anak gadis mereka sudah mengalami menstruasi atau haid maka sudah dapat dinikahkan agar tidak membuat aib dikeluarga jika anak gadis tersebut hamil diluar nikah, di samping itu bagi mereka anak gadis yang sudah berusia 20 tahun keatas jika belum menikah maka sudah dianggap perawan tua dan itu adalah aib bagi keluarga yang membuat keluarga menanggung siri atau malu. Sehingga, banyak diantara mereka saling menjodohkan anak-anak mereka walaupun masih tergolong dibawah umur, kejadian seperti itu terus

14Dalle, Wawancara, LumbuTarombo: Rumah bapak Dalle, 27 April 2018. 
berlanjut dan berbaur dengan suku lainnya seperti suku penduduk asli yaitu suku kaili hingga ditahun 90-an. Memasuki tahun 2000 ketika banyak anakanak daerah yang sudah berpendidikan tinggi dan berpengetahuan global serta lengkapnya pemerintah desa dengan pengaturan ketat penerapan perundang-undangan tentang perkawinan, akhirnya pernikahan diusia dini pun dapat diminimalisirkan, adapun kejadian pernikahan diusia dini di atas tahun 2000 karena alasan tertentu, bahkan pada tahun 2016 desa LumbuTarombo digemparkan dengan beberapa kejadian pernikahan usia dini sekaligus oleh beberapa pelajar tingkat SLTA dikarenakan pihak perempuan telah hamil diluar nikah. Bagi bapak Dalle sendiri sangat tidak setuju dengan adanya pernikahan diusia dini karena bagaimanapun bagusnya pemikiran dan tindakan para pelakunya tetap akan menyusahkan dan menjadi beban keluarga.

Pernikahan diusia dini tentunya menimbulkan banyak dampak baik dampak positif maupun dampak negatif terhadap pasangan yang menjalaninya tanpa terkecuali bagi anak-anak yang terlahir dari pernikahan tersebut, dalam penelitian tesis ini peneliti akan mengungkapkan satu persatu dampak terhadap pola asuh orangtua dan karakter anak yang terlahir dari pasangan yang menikah diusia dini, dampak tersebut peneliti dapatkan selama proses penelitian melalui metode observasi dan wawancara. Adapun dampaknya akan peneliti uraikan, sebagai berikut:

\section{Kekerasan Dalam Rumah Tangga (KDRT)}

Pasangan yang menikah diusia dini tentunya belum siap dan matang dari segi fisik dan psikis serta belum stabil dari sisi emosi, sehingga tidak heran bila KDRT rentan terjadi dalam rumah tangga pasangan yang menikah diusia dini baik itu dilakukan oleh suami terhadap istri ataupun anaknya atau dilakukan oleh istri terhadap suami ataupun anaknya. Seperti salah satu kasus yang peneliti dapatkan selama penelitian pada keluarga yang ketiga, yaitu keluarga bapak Samudra dan ibu Muri Astuti yang telah dikaruniai 2 orang anak perempuan, anak pertama bernama Aisyah berusia 5 tahun dan telah bersekolah di TK B serta anak kedua bernama Puji Astuti berusia 2 tahun 7 bulan dan bertempat tinggal dirumah mereka sendiri. Ibu Muri Astuti tidak pernah mengatur jadwal atau waktu bagi anak-anaknya, ketika anaknya ingin makan, mandi ataupun tidur maka disitulah baru ia beri makan, dan memandikan serta menidurkan anak-anaknya, dengan kata lain tidak ada waktu-waktu tertentu yang anaknya harus ikuti jika anaknya tidak ingin tidur siang maka anaknya pun tidak tidur siang. Ibu Muri Astuti termasuk ibu yang tempramen dan emosional bahkan pada suami dan anak-anaknya serta mertuanya. 
Kondisi emosi ibu Muri Astuti yang tidak stabil terkadang memicu terjadinya perselisihan dan pertengkaran antara dia dan suaminya hingga sering terjadi KDRT sesekali di selah-selah pertengkaran mereka, namun karena rasa malu dan rasa kekeluargaan yang sangat besar sehingga tidak pernah terjadi pertengkaran yang melibatkan pemerintah desa bahkan keluarga besar mereka jarang mengetahui bila mereka sedang bertengkar hebat sekalipun. Ibu Muri Astuti memberikan penjelasan mengenai cara mengasuh dan mendidik anak-anaknya serta karakter mereka sehari-hari, menurut ibu Muri Astuti bahwa:

Sang suami sangat memanjakan anak-anak, sehingga mereka sangat manja dan cengeng serta keras kepala. Namun, saya sangat keras terhadap anak-anak kesalahan kecil saja yang anak-anak perbuat langsung memancing emosi saya hingga tanpa sadar tangan saya dengan mudahnya memukul dan mencubit mereka bahkan sama yang kecil sekalipun. Pernah suatu hari anak pertama saya Aisyah tidak mendengarkan perkataan saya, dia terus bermain air di dapur dan tidak mau mandi saya berusaha menahan emosi namun dia terus membuat saya marah dan akhirnya saya pun mengusirnya keluar rumah dan menyuruhnya pergi kerumah neneknya yang tidak jauh dari rumah, hingga pada sore hari ketika suami pulang dari kerja di kebun dan menanyakan anaknya maka disitulah terjadi perselisihan hingga pertengkaran dan saya pun mendapatkan tamparan serta tendangan dari suami, setelah menampar dan menendang saya suami pun pergi kerumah mertua untuk menjemput anaknya. ${ }^{15}$

Pola asuh yang menurut peneliti cukup keras dan kasar ibu Muri Astuti memberikan kebebasan penuh terhadap anaknya namun apabila anaknya berbuat salah sekecilpun ibu Muri Astuti tidak segan-segan mencubit bahkan memukul sang anak walau usianya masih terlalu kecil. Anak pertama beliau berusia 5 tahun dan sudah sekolah TK B namanya adalah Aisyah dia anak yang mudah diatur, manja dan cengeng namun temasuk siswa berprestasi di sekolahnya. Sedangkan anak keduanya bernama Puji Astuti adalah anak yang mandiri dan keras hati walaupun usianya baru 2 tahun lebih namun karakternya dapat dilihat dari kesehariannya yang makan sendiri tanpa disuap dan ingin mandi sendiri jadi ibunya hanya mengawasi saja. Aisyah termasuk siswa berprestasi dibenarkan oleh ibu Lisdawati Ilyas selaku guru kelas Aisyah, menurut ibu Lisda:

15Muri Astuti, Wawancara, LumbuTarombo: Rumah kediaman ibu Muri, 14 Mei 2018. 
Aisyah adalah anak yang menyenangkan diusianya yang masih tegolong lebih muda dari teman-temannya namun dia mampu dengan mudah untuk beradaptasi dan berteman sama siapa saja walaupun beda kelas, dia adalah anak yang periang, manja, cengeng tapi cerdas karena dia sangat memperhatikan pelajarannya terbukti dengan nilai-nilainya yang memuaskan. ${ }^{16}$

Berdasarkan keterangan ibu Lisdawati Ilyas mengenai karakter Aisyah dan prestasinya disekolah serta keterangan dari ibu Muri Astuti tentang kesehariannya dalam mendidik anak-anaknya, maka peneliti berpendapat bahwa ibu Muri menerapkan pola asuh yang menurut Rifa Hidayah dalam bukunya Bimbingan Konseling di Sekolah adalah pola pengasuhan autoritatif, yaitu:

Pola pengasuhan autoritatif. Pola pengasuhan ini memprioritaskan kepentingan anak dibandingkan dengan kepentingan dirinya sendiri, namun mereka tidak ragu-ragu mengendalikan anak. Hal ini dapat membimbing anak untuk mandiri dan independen. ${ }^{17}$

Pola pengasuhan autoritatif yang ibu Muri terapkan dapat dilihat dari caranya ibu dalam mendidik anak-anaknya sehari-hari yang tidak waktuwaktu tertentu yang wajib anaknya turuti seperti makan, mandi dan tidur semua terserah dari anaknya kapanpun anaknya mau makan, mau mandi dan mau tidur baru dia mengerjakannya. Namun, apabila anaknya tidak ingin tidur siang maka anaknya pun tidak akan tidur siang tidak ada peraturan dan paksaan dari ibu Muri untuk anak-anaknya, Namun, apabila anak-anaknya melakukan kesalahan ibu Muri tida segan-segan menegur bahkan menghukum anak-anaknya. Oleh Karena itu ia memiliki anak pertama yng cerdas dan termasuk anak berprestasi dan anak keduanya yang mandiri walau masi sangat kecil.

\section{Berpotensi Keguguran}

Menurut Sosiolog Universitas Gajah Mada (UGM), Prof. Dr. Partini, bahwa:

Perempuan yang menikah di bawah usia 18 tahun berpotensi keguguran, anak dan ibu rentan terhadap penyakit, kualitas anak yang dilahirkan rendah, gizi buruk dan putus sekolah, resiko menurunnya kesehatan reproduksi, beban ekonomi yang makin

16Lisdawati Ilyas, Wawancara, kelas TK B, LumbuTarombo 17-19 Mei 2018.

${ }^{17}$ Rifa Hidayah, Bimbingan Konseling di Sekolah, (Jakarta: Bumi Aksara, 2009), 54. 
bertambah berat, kekerasan dalam rumah tangga, perceraian dan bunuh diri. 18

Sehubungan pendapat di atas peneliti menemukan dilokasi penelitian bahwa pada keluarga kelima keluarga bapak Ali'duding dan ibu Hariani. Ibu Hariani menikah diusia 14 tahun dikarenakan perjodohan dari orangtua mereka yang masih ada hubungan keluarga. Diusia 14 tahun ibu Hariani masih sangat belia dan belum matang dari segi biologisnya sehingga pada kehamilan anak pertama ibu Hariani mengalami kesulitan selama proses kehamilan yang dikenal dengan kata mengidam yang pada akhirnya ibu Hariani tidak mampu mempertahankan calon anaknya hingga ia pun mengalami keguguran dan kehilangan calon anak pertama mereka. Hal tersebut membuat ibu Hariani dan keluarga besar mereka sangat terpukul karena anak tersebut adalah calon cucu pertama dikeluarganya.

\section{Otoriter}

Menurut Rifa Hidayah dalam bukunya Bimbingan Konseling di Sekolah bahwa pola pengasuhan otoriter adalah:

Pola pengasuhan otoriter adalah pola pengasuhan dimana orangtua menilai dan menuntut anak untuk mematuhi standar mutlak yang ditentukan sepihak oleh orangtua atau pengasuh, memutlakkan dan kepatuhan dan rasa hormat atau sopan santun. Anak-anak dalam pengasuhan ini cenderung menarik diri secara social, kurang sopan dan tampak kurang percaya diri. ${ }^{19}$

Berdasarkan penjelasan di atas, peneliti menemukan selama penelitian terdapat 1 keluarga yang menerapkan pola asuh otoriter, semua ditentukan oleh orangtua khususnya sang ibu sebagai pembuat peraturan yang harus ditaati oleh anak-anaknya, semua punya jadwal tertentu mulai dari waktu makan, mandi, tidur dan bermain serta waktu dimana sang anak harus melakukan salah satu tugas rutin dari ibunya seperti mencuci piring ataupun membersihkan rumah.

Keluarga yang menerapkan pola asuh otoriter tersebut adalah keluarga kedua yang menjadi objek penelitian peneliti, mereka adalah bapak Kadir dan ibu Cici Lestari. Bapak Kadir dan ibu Cici Lestari dikarunia 2 orang anak, anak pertamanya bernama Irfan usia 8 tahun dan duduk di kelas 3 SD sedangkan anak keduanya bernama Razak berusia 6 tahun dan duduk di kelas 1 SD. Dalam kesehariannya ibu Cici Lestari sangat disiplin dalam mengasuh dan mendidik anak-anaknya, semua pekerjaan dan waktu sang

\footnotetext{
${ }^{18}$ Mahesa Danu, Ini Dampak Negatif Pernikahan Usia Dini, Kabar Rakyat: www. Berdikarionline.com. Diakses 3 Agustus 2018.

${ }^{19}$ Hidayah, Bimbingan, 54.
} 
anak diatur oleh ibunya. Maka tidak heran bila anak-anaknya mampu membantunya mengerjakan pekerjaan rumah sehari-hari seperti membantu mencuci piring dan membersihkan rumah. Menurut ibu Cici Lestari sikap dan karakter anak-anaknya sehari-hari, yaitu:

Anak pertama saya bernama Irfan adalah tipe anak yang mandiri, disiplin, mudah diberi nasehat dan mudah diatur namun lambat memahami apa yang telah saya jelaskan berbeda dengan anak kedua saya bernama Razak yang sangat cengeng, manja, keras kepala dan banyak bermain. ${ }^{20}$

Berbeda dengan keterangan yang diberikan oleh ibu Cici Lestari tentang kedua anaknya. Guru-guru sekolah mereka malah memberikan katerangan yang jauh berbeda dengannya. Menurut ibu Pratiwi guru kelas dari Irfan anak pertama ibu Cici Lestra bahwa:

Irfan adalah anak yang tidak berprestasi karna sangat usil dan jail terhadap teman-temannya, kurang percaya diri terhadap hasil pelajarannya, sangat lamban dalam menerima pelajaran banyak cerita di dalam kelas dan bermain serta tidak memperhatikan pelajaran saat guru menjelaskan. ${ }^{21}$

Senada dengan ibu Pratiwi, ibu Senna, S. Pd selaku guru kelas dari Razak anak kedua bapak Kadir dan ibu Cici Lestari bahwa:

Razak adalah anak yang tidak berprestasi karna sifat usil dan jailnya terhadap teman-temannya membuat ia banyak bermain dan tidak focus memperhatikan pelajaran saat proses belajar mengajar berlangsung, Razak juga tipe anak yang kurang percaya diri saat diberi tugas dan kurang percaya terhadap hasil tugas yang dikerjakannya. ${ }^{22}$

Berdasarkan hasil penelitian pada keluarga bapak Kadir dan ibu Cici Lestari, peneliti memahami bahwasanya pola pengasuhan otoriter sangatlah tidak baik untuk diterapkan, karena akan berdampak buruk pada karakter dan prilaku anak ketika tidak bersama orangtuanya. Misalnya saja pada anakanak bapak Kadir dan ibu Cici lestari yang apabila dirumah adalah anak yang mandiri, sopan, disiplin dan menjadi kebanggaan bagi orangtuanya yang sepintas dapat dikategorikan sebagai anak-anak yang baik dan harusnya

${ }^{20}$ Cici Lestari, Wawancara, Rumah Ibu Cici Lestari, LumbuTarombo 30 April 2018.

21Pratiwi. A, Ma, Wawancara, Gedung sekolah SDN LumbuTarombo, LumbuTarombo 7-11 Mei 2018.

22Senna, wawancara, Gedung sekolah SDN LumbuTarombo, LumbuTarombo 3-5 Mei 2018. 
berprestasi, ternyata bertolak belakang dengan prilaku mereka ketika tidak bersama orangtuanya. Seperti pada saat di sekolah mereka adalah anak-anak yang tidak berprestasi karna sangat jail dan usil serta kurang percaya diri dalam pelajaran, banyak bermain dan tidak memperhatikan pelajaran saat proses belajar mengajar berlangsung.

\section{Posesif}

Posesif dalam Kamus Besar Bahasa Indonesia (KBBI) diartikan sebagai sifat merasa menjadi pemilik atau mempunyai sifat cemburu. ${ }^{23}$ Sifat posesif peneliti temukan hampir pada semua keluarga ( 5 keluarga) yang menjadi objek penelitian, namun yang sangat berpengaruh terhadap pola asuh orangtua hingga berdampak pada karakter anak terdapat pada keluarga pertama bapak Hasriadi dan ibu Yusnaini serta pada keluarga keempat bapak Moh. Syarif dan ibu Mutmaiddah.

Moh. Hasriadi dan Yusnaini dikaruniai 1 anak 3 bulan selepas pernikahan mereka, mereka tinggal bersama orangtua Yusnaini dan Hasriadi bekerja bersama orangtuanya. Kesehariannya dalam mengasuh dan mendidik anak Yusnaini masih dibantu oleh ibunya hanya saja karena usia yang masih muda dengan emosi yang belum stabil membuat Yusnaini kadang bersikap keras dan kasar terhadap anaknya walau masih balita dan terkadang bersuara keras terhadap orangtuanya kadangkala ketika diberikan nasehat serta sangat posesif terhadap suaminya yang bekerja sebagai supir angkutan umum. Moh. Hasriadi jarang dirumah jika siang karena harus mencari nafkah sehingga dalam mengasuh dan mendidik anaknya diberikan penuh terhadap istrinya. Moh. Hasriadi sangat memanjakkan anaknya, aktifitas anaknya sehari-hari sama dengan anak-anak pada umumnya ada waktu-waktu tertentu yang sudah diatur oleh ibunya untuk mandi, makan, tidur dan bermain.

Sifat posesif yang dimiliki ibu Yusnaini terkadang mengundang perselisihan diantara ia dan suaminya yang berdampak pada prilakunya terhadap anaknya, sehingga ia terkadang bersikap keras dan kasar terhadap anaknya walau masih balita dan membuat anaknya tumbuh menjadi pribadi yang cengeng, manja dan keras kepala serta susah diatur. Sebagaimana penuturan ibu Yusnaini yaitu:

Sikap dan karakter anak sehari-hari susah diatur, manja, cengeng, pemarah dan tidak sabaran. Selama pernikahan saya dan suami

${ }^{23}$ Ebta Setiwan, Kamus Besar Bahasa Indonesia (KBBI) versi online/daring (dalam jaringan), (data base online). Hak cipta Badan Pengembangan dan Pembinaan Bahasa, kemdikbud (pusat bahasa), https://kbbi.web.id/posesif.html. Diakses Jumat, 3 Agustus 2018, 2 baris. 
tidak pernah mengalami perselisihan atau pertengkaran yang serius, karena suami selalu mengalah terhadap kemauan saya, namun bila saat suami kerja seharian atau bahkan tidak pulang tanpa kabar berita serta bila suami tidak kerja sehari atau dua hari itu merupakan hal-hal yang dapat mengundang perselisihan diantara kami yang tidak jarang berujung pada perkelahian. ${ }^{24}$

Sikap dan prilaku ibu Yusnaini yang kurang baik tersebut dibenarkan oleh bapak kandungnya sendiri, sebagaimana penjelasannya yaitu: Menurut bapak Ali bapak dari Yusnaini bahwa bapak Hasriadi sebagai menantu dimatanya adalah menantu yang baik, bisa diatur, tidak gampang tersinggung dan mudah diberikan nasehat. Bertolak belakang dengan Yusnaini anak kandungnya sendiri yang keras kepala, susah diberikan nasehat dan gampang marah bahkan terhadap anak bayinya sendiri. ${ }^{25}$

Selain keluarga bapak Moh. Hasriadi dan ibu Yusnaini sifat posesif juga terdapat pada keluarga bapak Moh. Syarif dan ibu Mutmaiddah. Peneliti melihat bahwa pasangan suami istri tersebut sama-sama memiliki sifat posesif hanya saja ibu Mutmaiddah cenderung pendiam dan menurut apa kata suaminya karena takut padanya. Ibu Mutmaiddah takut pada suaminya dikarenakan selain sifat posesif yang dimiliki bapak Moh. Syarif ia juga terkenal dengan emosional atau temperamental, sifat keras dan kasar terhadap istrinyapun berimbas pada pola asuh mereka terhadap anaknya.

Urusan mengasuh dan mendidik anak bapak Moh. Syarif lebih dominan dibanding sang istri. Karena menurut bapak Kamran bahwa anaknya sangatlah keras kepala dan tempramen, emosional sehingga sering berselisih dengannya beruntung memiliki menantu atau istri bapak Syarif seorang perempuan yang pendiam dan penurut akhirnya sang istrilah yang sering mengalah. ${ }^{26}$. Karena sikap keras dan tempramen dari bapak Syarif membuat anaknya menjadi anak yang cengeng dan pemarah serta susah diatur walau masih berusia 1 tahun 10 bulan namun karakter tersebut sudah dapat dilihat dalam kesehariannya.

\section{Faktor-Faktor Pendukung Dan Penghambat Terjadinya Pernikahan Usia Dini}

\section{Faktor-faktor yang mendukung terjadinya pernikahan diusia dini.}

Banyak faktor yang dapat menjadi pendukung terjadinya pernikahan diusia dini. Secara umum faktor yang banyak berkontribusi terjadinya pernikahan terhadap anak diusia dini antara lain: faktor agama, faktor

${ }^{24}$ Yusnaini, Wawancara, rumah bapak Ali, J. LumbuTarombo 26 April 2018.

25Ali. J, Wawancara, Rumah bapak Ali. J, LumbuTarombo 27 April 2018.

26Kamran, Wawancara, Lumbutarombo 23 Mei 2018 
budaya (adat), faktor sosial, dan faktor hukum yang berkembang dalam suatu masyarakat.

Menurut bapak Rahmat, SS selaku penghulu Kantor Urusan Agama (KUA) di Kec. Banawa Selatan Kab. Donggala mengatakan bahwa sebagian besar masyarakat Kec. Banawa Selatan menikah diusia muda adapun beberapa yang menikah diusia dini tidak terhitung atau tidak terdaftar di KUA sehingga pernikahannya termasuk pernikahan siri, bagi pasangan yang melangsungkan pernikahan diusia dini dan pernikahan siri bila ingin melegalkan pernikahan mereka maka pernikahan tersebut masuk pada isbat nika agar mereka memiliki buku nikah. Jika ada yang terdaftar di KUA dan mereka pada kenyataannya masih tergolong dibawah umur maka hal tersebut mengalami kesalahan baik terdapat pada keluarga maupun pemerintah desa. Untuk faktor-faktor yang mempengaruhi banyaknya pernikahan usia muda antara lain adalah: faktor ekonomi, faktor tradisi perjodohan, faktor pendidikan rendah dan akibat pergaulan bebas. ${ }^{27}$

Berdasarkan hasil wawancara mendalam dari beberapa informan peneliti menemukan beberapa alasan bagi pasangan yang melakukan pernikahan diusia dini atau faktor-faktor yang mendukung terjadinya pernikahan diusia dini di Desa Lumbu Tarombo, Kecamatan Banawa Selatan, Kabupaten Donggala, antara lain:

\section{a. Faktor Sosial (Kebiasaan)}

Dari segi sosial, di dalam masyarakat atau kebiasaan yang sudah biasa pada satuan terkecil (keluarga) yang mendorong sikap pro atau sikap mendukung yang sudah biasa terhadap pernikahan usia dini. Termasuk di dalamnya faktor rendahnya pendidikan dan tingkat minimnya perekonomian serta sikap atau pandangan masyarakat yang biasanya meremehkan masalah pergaulan bebas sehingga terjadilah pernikahan di bawah umur atau pernikahan diusia dini. Hal tersebutlah yang peneliti temukan pada keluarga pertama bapak Moh. Hasriadi berusia 15 tahun pada waktu menikah dan ibu Yusnaini berusia 16 tahun pada waktu menikah, mereka menikah karena alasan pergaulan bebas yang mengakibatkan ibu Yusnaini hamil diluar nikah dan terpaksa harus menikah. Hal yang samapun peneliti temukan pada keluarga yang keempat bapak Moh. Syarif berusia 21 tahun pada saat menikah dengan ibu Mutmaidah berusia 15 tahun pada saat menikah dan telah memiliki 1 orang anak serta masih tinggal bersama orangtua, mereka menikah karena pergaulan bebas yang akhirnya membuat Mutmaidah hamil

${ }^{27}$ Rahmat, SS, Wawancara, Gedung Kantor Urusan Agama (KUA), Lembasada 25 April 2018. 
diluar nikah walau pada saat itu ia masih duduk dibangku kelas 1 SMK. Kedua keluarga tersebut masilah sangat dini untuk menikah namun mereka terpaksa menikah dikarenakan pergaulan bebas yang mengakibatkan pihak perempuan hamil sebelum menikah.

\section{b. Faktor Budaya (Tradisi)}

Faktor budaya atau tradisi yang masih melekat dibeberapa masyarakat didaerah Indonesia dan sebagian menganggap bahwa pernikahan diusia dini atau perkawinan di bawah umur merupakan tindakan yang biasa. Bahkan dalam sebagian besar masyarakat Indonesia beranggapan bahwa menjadi suatu kebanggaan jika anak gadisnya pada usia muda sudah dilamar dan dinikahi oleh laki-laki lain. Hal ini karena adat atau kebiasaan yang masih melekat dimasyarakat yang ikut serta mempengaruhi cara berpikir masyarakat.

Sebagian masyarakat berpendapat bahwa tidak ada larangan nikah di bawah umur, serta meyakini suatu kepercayaan bahwa seorang anak perempuan yang sudah dilamar harus diterima, bila tidak diterima bisa berakibat si anak tidak laku (tidak dapat jodoh) bahkan ada pula sebagian masyarakat yang berprinsip bahwa apabila anak mereka sudah haid (mengalami menstruasi pertama) maka boleh dinikahkan jika tidak dinikahkan maka orangtua merasa khawatir bila sang anak akan membawa aib bagi keluarga jika anak tersebut hamil diluar nikah, adapula yang berpendapat bahwa apabila anak gadis mereka sudah berusia 20 tahun dan belum menikah maka anak tersebut akan menjadi aib keluarga karena dianggap sebagai perawan tua. Hal tersebutlah yang peneliti temukan pada keluarga yang kelima yaitu bapak Ali du'ding berusia 28 tahun pada saat menikah dengan ibu Hariani yang berusia 14 tahun pada saat menikah, mereka menikah atas perjodohan orangtua mereka yang mana mereka masih ada hubungan keluarga. Ibu Hariani adalah anak gadis satu-satunya dari bapak Ambotang yang masih memegang prinsip dan tradisi kuno keluarga bugis mengenai anak gadis yang sudah menstruasi atau haid alangkah lebih baiknya segera dinikahkan sebelum membawa siri atau malu karena hamil diluar nikah dan anak gadis yang berusia 20 tahun ke atas bila belum menikah maka akan membawa aib bagi keluarga karena sudah dianggap perawan tua sehingga diusia 14 tahun Hariani pun dijodohkan dengan salah satu anggota keluarga dari bapak Ambotang yaitu bapak Ali du'ding.

\section{c. Faktor Cinta}

Faktor cinta menjadi salah satu faktor yang peneliti temukan di lapangan, karena alasan cinta membuat pernikahan diusia dini pun dapat terjadi, walaupun pada awalnya mendapat penolakan dari keluarga karena 
dianggap masih terlalu dini untuk menikah. Namun, dikarenakan faktor cinta akhirnya pernikahan diusia dini pun tidak dapat dihindari. Hal tersebutlah yang peneliti temukan pada keluarga yang ketiga bapak Samudra berusia 25 tahun pada saat menikah dengan ibu Muri Astuti berusia 15 tahun pada saat menikah, mereka menikah dengan alasan karena cinta walaupun pada awalnya mendapat penolakan dari pihak keluarga laki-laki karena menganggap pihak perempuan masih terlalu dini bahkan sempat gagal 3 kali pada saat lamaran karena perselisihan pihak keluarga masing-masing, namun pada akhirnya mereka pun dapat melangsungkan pernikahan. Senada dengan keluarga yang kedua bapak Kadir berusia 18 tahun pada saat menikah dengan ibu Cici Lestari berusia 14 tahun pada saat menikah, mereka menikah karena alasan cinta dan ekonomi karena pada saat itu ibu Cici Lestari adalah anak korban dari perceraian orangtua yang mengakibatkan dia harus tinggal bersama kakek dan neneknya yang kurang mampu sehingga pada saat duduk di kls 1 SLTP dia berpacaran dengan bapak Kadir kurang lebih sebulan dan langsung menikah, walaupun sempat mendapat penolakan dari pihak laki-laki karena menganggap mereka (laki-laki dan perempuan) yang mau menikah masih terlalu dini. Namun, cinta mereka tidak dapat menunggu lagi atau tidak dapat sabar menanti hingga pihak perempuan lulus sekolah dan pada akhirnya pernikahan diusia dinipun tidak dapat dihindari.

Berdasarkan pendapat dan hasil penelitian di atas, peneliti menyimpulkan bahwasanya pernikahan usia dini di desa Lumbutarombo Kecamatan Banawa Selatan Kabupaten Donggala didukung oleh beberapa faktor seperti perjodohan yang tergolong pada faktor budaya atau tradisi, ekonomi dan akibat pergaulan bebas yang tergolong pada faktor sosial atau kebiasaan masyarakat serta faktor cinta. Sehingga bagi peneliti pentingnya perhatian pemerintah untuk memberikan penyuluhan agar masyarakat memahami bahwa pernikahan diusia dini lebih banyak mendatangkan dampak negatif dengan tujuan pernikahan diusia dini dapat diminimalisirkan bila perlu dihentikan.

Pemerintah desa Lumbu Tarombo telah menerapkan Undang-undang Perkawinan yang mengharuskan pasangan boleh menikah bila pihak perempuan berusia 16 tahun dan pihak laki-laki berusia 19 tahun namun masyarakat masih bisa mengelabui pemerintah desa dengan menaikkan usia anak-anak mereka melalui rekayasa pada akte kelahiran mereka sehingga diakte kelahiran usia anak mereka lebih dewasa dibanding usia yang sesungguhnya. Oleh karena itu pentingnya perhatian pemerintah terhadap masyarakat yang masih berfikiran dan berprinsip bahwa anak-anak perempuan yang sudah mengalami haid atau menstruasi harus segera 
dinikahkan dan anak-anak perempuan yang sudah berusia 20 tahun dianggap sebagai perawan tua yang akan menjadi aib bagi keluarga.

\section{Faktor-Faktor yang menghambat terjadinya pernikahan diusia dini.}

Pada pemaparan sebelumnya peneliti telah menjelaskan pendapat dari salah satu tokoh masyarakat sekaligus penduduk asli didesa Lumbu Tarombo Kecamatan Banawa Selatan, Kabupaten Donggala, bahwasanya di desa tersebut fenomena pernikahan diusia dini dimulai pada era 70-an hingga 90an. Memasuki tahun 2000 pernikahan diusia dini mulai berkurang bahkan jarang terjadi dikarenakan banyaknya anak-anak daerah yang telah berpendidikan tinggi dan berwawasan global sehingga membawa pengaruh besar terhadap wawasan dan pengetahuan masyarakat sekitar tentang bahayanya menikah diusia dini.

Pernikahan diusia dini memang membawa dampak positif bagi pasangan yang melakukannya. Namun, dibalik dampak positifnya pernikahan diusia dini cenderung lebih banyak menimbulkan dampak negatif yang sangat merugikan pasangan yang menjalinya terlebih dari pihak perempuan dan anak-anak yang terlahir dari pernikahan tersebut. Begitu banyak dampak negatif yang ditimbulkan dari pernikahan diusia dini sehingga pemerintah telah mengatur batas usia diperbolehkannya melangsungkan pernikahan dalam Undang-undang Perkawinan No 1 tahun 1974 yang mengatur usia minimal pihak laki-laki 19 tahun dan pihak perempuan 16 tahun untuk dapat melangsungkan pernikahan.

Setelah memisahkan diri dari daerah Tolongano tepatnya ditahun 2008 desa Lumbu Tarombo pun mulai mengatur pemerintahannya dengan otonomi daerah tersendiri tanpa bergantung lagi dari desa Tolongano. Dengan struktur organisasi pemerintah desa yang lengkap sehingga aturan undang-undang tentang batas usia diperbolehkannya menikah jika laki-laki berusia 19 tahun ke atas dan perempuan 16 tahun ke atas mulai diterapkan dan diberlakukan, hal tersebut membuat pernikahan usia dini di desa Lumbu Tarombo menjadi berkurang dan jarang terjadi, adapun terjadinya pernikahan diusia dini diatas tahun 2000-an dikarenakan alasan-alasan tertentu yang mengharuskan pernikahan tersebut terpaksa dilangsungkan, misalnya dikarenakan pihak perempuan telah hamil diluar nikah.

Selain faktor penerapan Undang-undang pernikahan pendidikan masyarakatpun menjadi salah satu faktor penghambat terjadinya pernikahan diusia dini. Dengan, pendidikan anak-anak daerah yang semakin tinggi dan wawasan yang semakin luas membawa pengaruh besar terhadap pengetahuan orangtua dan keluarga mereka serta masyarakat sekitar tentang banyaknya dampak negatif dari pernikahan diusia dini. Anak-anak daerah yang kembali dari luar daerah dengan membawa segudang 
pengetahuan mereka dan mengabdi pada masyarakat Lumbu Tarombo mengakibatkan pernikahan diusia dini dapat diminimalisirkan. Dengan pengetahuan yang mereka miliki pada akhirnya para orangtua dan masyarakat sekitar mengetahui dan memahami bahwa menikah diusia dini sangat tidak baik karna lebih banyak menimbulkan dampak negatif dibanding dampak positif khususnya bagi pihak perempuan dan anak-anak yang terlahir dari pernikahan tersebut.

Diterapkannya UU No. 1 Tahun 1974 tentang perkawinan serta semakin banyaknya anak-anak daerah yang berpendidikan tinggi dan berwawasan global membuat pernikahan usia dini di desa Lumbu Tarombo dapat diminimalisirkan, sehingga pernikahan diusia dini semakin berkurang. Itulah faktor penghambat terjadinya pernikahan usia dini di desa Lumbu Tarombo Kecamatan Banawa Selatan, Kabupaten Donggala.

Berdasarkan uraian di atas dan hasil wawancara mendalam yang peneliti lakukan dengan informan, peneliti menemukan satu kunci sukses pernikahan diusia dini di Desa Lumbu Tarombo, Kecamatan Banawa Selatan, yang menjadi alasan mengapa pernikahan mereka terlihat bahagia tanpa adanya masalah yang serius padahal mereka masilah para remaja yang tentunya belum siap dan matang dari segi psikis serta belum stabil dari segi emosi tapi mereka mampu mempertahankan rumah tangga yang mereka bina walau terkadang mengalami kekerasan baik fisik maupun psikis baik suami maupun istri tapi mereka mampu menyembunyikan masalah yang mereka hadapi, jangankan dimata masyarakat dimata keluarga besar mereka pun tidak pernah terlihat akan hal tersebut. Semua hal tersebut terjadi karena mereka memiliki sifat malu (siri dalam bahasa bugis berarti malu) dan rasa kekeluargaan yang tinggi, sehingga mereka mampu mempertahankan rumah tangga mereka dan mampu menutupi segala masalah yang mereka hadapi hingga pada akhirnya keluarga mereka bahagia, nyaman, tentram dan sejahtra.

\section{Kesimpulan}

Berdasarkan hasil penelitian yang diuraikan sebelumnya, maka peneliti dapat mengambil kesimpulan sebagai berikut:

1. Berdasarkan hasil yang diperoleh, peneliti memahami dan menyadari bahwa pernikahan diusia dini membawa banyak dampak negatif terhadap pasangan yang menjalaninya terkhusus bagi mereka pihak perempuan. Adapun dampak pernikahan usia dini yang berpengaruh terhadap pola asuh orang tua dan karakter anak yang peneliti temukan di desa Lumbu Tarombo, Kecamatan Banawa Selatan, Kabupaten Donggala, antara lain: a. 
Kekerasan Dalam Rumah Tangga (KDRT); b. Berpotensi Keguguran; c. Otoriter; d. Posesif.

2. Ada beberapa faktor yang mendukung dan menghambat terjadinya pernikahan diusia dini. Faktor-faktor yang mendukung terjadinya pernikahan usia dini di desa Lumbu Tarombo antara lain: perjodohan yang tergolong pada faktor budaya atau tradisi, ekonomi dan akibat pergaulan bebas yang tergolong pada faktor sosial atau kebiasaan masyarakat serta faktor cinta. Sedangkan faktor yang menghambat terjadinya pernikahan usia dini adalah diterapkannya UU No. 1 Tahun 1974 tentang perkawinan serta semakin banyaknya anak-anak daerah yang menempuh pendidikan formal hingga menambah wawasan mereka.

Sebagai tindak lanjut penelitian yang peneliti lakukan, maka ada beberapa saran yang ingin peneliti sampaikan, antara lain:

1. Untuk pemerintah desa Lumbu Tarombo, Kec. Banawa Selatan Kab. Donggala, peneliti mengharapkan adanya sosialisasi terhadap seluruh masyarakat akan dampak yang ditimbulkan dari pernikahan diusia dini yang lebih cenderung berdampak negatif khususnya terhadap perempuan, jika perempuan belum matang dari segi fisiknya dan sering berhubungan badan maka akan ditakutkan mudahnya perempuan tersebut terjangkit penyakit kanker rahim serta beresiko tinggi meninggal bila melahirkan diusia yang masih sangat muda. Dengan adanya sosialisasi tersebut peneliti mengharapkan hilangnya prinsip dan tradisi masyarakat yang beranggapan bahwa anak gadis yang sudah menstruasi harus segera dinikahkan serta apabila berusia 20 tahun ke atas dianggap perawan tua sehingga menjadi beban keluarga, peneliti sangat berharap prinsip dan tradisi demikian dapat hilang dengan adanya sosialisasi dari pemerintah.

2. Kepada masyarakat desa Lumbu Tarombo, Kec. Banawa Selatan, Kab. Donggala, khususnya terhadap orangtua yang memiliki anak-anak remaja apalagi remaja putri haruslah dipantau pergaulannya, jalinlah komunikasi yang baik antara orangtua dengan anak agar anak-anak tidak terjerumus kedalam pergaulan bebas yang merenggut masa remajanya dan memudarkan impian dan cita-citanya dibangku sekolah karena masa depan bangsa terletak ditangan para pemuda dan pemudi.

3. Untuk ibu-ibu desa Lumbu Tarombo Kec. Banawa Selatan, Kab. Donggala yang telah menikah diusia dini dan telah memiliki anak, agar sekiranya ibu-ibu mampu mengendalikan emosi saat menghadapi sibuah hati. Untuk mendapatkan hati yang tenang agar emosi dapat stabil maka perdekatlah hubungan dengan sang pencipta dan mencobalah lebih sabar menghadapi suami, dengan begitu akan mendapatkan hati yang tenang sehingga mampu mengasuh dan mendidik anak tanpa emosional sehingga 
terbentuklah anak-anak yang berkarakter budi pekerti luhur, karena anakanak adalah penerus generasi bangsa dan Negara serta agama.

\section{Daftar Pustaka}

Adpriyadi, Adpriyadi, and Sudarto Sudarto. "Pola Asuh Orang Tua Dan Implikasinya Terhadap Pendidikan Anak Usia Dini Pada Subsuku Dayak Inggar Silat." Vox Edukasi: Jurnal Ilmiah Ilmu Pendidikan, 2019. https://doi.org/10.31932/ve.v10i2.538.

Afriani, Riska, and Mufdlilah. "Analisis Dampak Pernikana Dini Pada Remaja Putri Di Desa Sidoluhur Kecamatan Godean Yogyakarta." Rakernas Aipkema, 2016.

Agus Mahfudin; Khoirotul Waqi'ah. "Pernikahan Dini Dan Pengaruhnya Terhadap Keluarga Di Kabupaten Sumenep Jawa Timur." Hukum Keluarga Islam, 2016.

An Nabhani, T. An Nizham Al Ijtima'I fi Al Islam. Bandung: PT Al-Ma'arif, 1990.

Danu, M. Ini Dampak Negatif Pernikahan Usia Dini, Kabar Rakyat: www. Berdikarionline.com. (Diakses 3 Agustus 2018).

Garliah, Lili dkk. 2005. Peran Pola Asuh Orangtua dalam Memotivasi Berprestasi. Jurnal Psikologi, Vol. I, No. I.

Hidayah, R. Bimbingan Konseling di Sekolah, Jakarta: Bumi Aksara, 2009.

http://digilib.uin-suka.ac.id/21882/1/1420310095_BAB-I_IV-atau-V_Daftar Pustaka.pdf.

https://journal.ugm.ac.id/jurnalpemuda/article/viewFile/32033/19357.

http://jurnal.poltekkes-malang.ac.id/berkas/fd47-Pola_Asuh_Anak.pdf.

http://repository.uinjkt.ac.id/dspace/bitstream/123456789/21872/1/ZUL KIFLI\%20AHMAD-FDK.pdf

Mahkamah Agung RI, Undang-Undang Republik Indonesia No. 3 Tahun 2006, MARI: Jakarta, 2006.

Muallifah. Pshyco Islamic Smart Parenting. tt: Diva Press Anggota IKAPI, 2009. Setiawan, E, Kamus Besar Bahasa Indonesia (KBBI) versi online/daring (dalam jaringan), (data base online). Hak cipta Badan Pengembangan dan Pembinaan Bahasa, kemdikbud (pusat bahasa), https://kbbi.web.id/dampak. Diakses Rabu, 13 Maret 2018, 10 baris.

Thoha, dkk. Metodologi Pengajaran Agama. Yogyakarta: Pustaka Pelajar, 2004.

Undang-undang Republik Indonesia Nomor 1 tahun 1974, Bab 1 pasal 1, 2, 3, 7.

Undang-undang Republik Indonesia No. 23 Tahun 2002 tentang Perlindungan anak Bab IV Pasal 26 ayat 1.

Undang-Undang RI Nomor 52 Tahun 2009 Tentang Perkembangan Kependudukan dan Pembangunan Keluarga, Pasal I ayat 6. 